\title{
Biologia
}

June 2011, Volume 66, Number 3, Pages 418-424

http://dx.doi.org/10.2478/s11756-011-0029-y

(c) 2011 Institute of Botany, Slovak Academy of Sciences. Springer

\section{Prorocentrum rivalis sp. nov. (Dinophyceae) and its phylogenetic affinities inferred from analysis of a mixed morphological and LSU rRNA data set}

\author{
David Delmail ${ }^{1,{ }^{*}}$, Pascal Labrousse $^{1},{\text { Philippe } \text { Crassous }^{2}, \text { Philippe Hourdin }^{1}, \text { Mathieu Guri }}^{3}$ \\ \& Michel Botineau ${ }^{1}$
}

\author{
${ }^{1}$ University of Limoges, Faculty of Pharmacy, Laboratory of Botany and Cryptogamy, GRESE (Research Group \\ on Water, Soil and the Environment) EA 4330, 2 rue du Docteur Marcland, F-87025 Limoges, France. \\ 2 IFREMER Brest, LEP (Laboratory of Deep Environments), DEEP (Department of Deep Ecosystems Studies), \\ BP70, F-29280 Plouzané, France. \\ ${ }^{3}$ IFREMER Brest, LM2E (Laboratory of Microbiology of Extreme Environments), UMR 6197, BP 70, F-29280 \\ Plouzané, France. \\ *: Corresponding author : David Delmail, Tel.: +33 555435 841; fax: +33 555435850 \\ email address : david.delmail@wanadoo.fr
}

\begin{abstract}
:
A new freshwater epiphytic Prorocentrum species, Prorocentrum rivalis, from the temperate region of the Haute-Vienne, France, is described. This species is the third freshwater species identified among approximately 60 marine Prorocentrum species. This new species is described using scanning electron microscope and phylogenetic analyses by a polyphasic approach (LSU rRNA sequences combined with 9 morphological characters). The phylogenetic analysis attests that $P$. rivalis is close to other planktonic freshwater species and the freshwater Prorocentrum clade is evolutionarily derived from an epiphytic freshwater prorocentroid ancestor. The unique marine species in the freshwater clade results from an ecophysiological reversion. $P$. rivalis differs from other epiphytic taxa by its rarity, its temperate distribution and its ecophysiological needs. The phylogeny confirms also that all planktonic Prorocentrum species are evolutionarily derived from epiphytic/benthic ancestors.
\end{abstract}

Keywords : Prorocentrum rivalis - epiphytic microalgae - LSU - phylogeny - polyphasic approach SEM 


\section{Introduction}

The dinoflagellate genus Prorocentrum Ehr. consists of about 60 validly published and identifiable species (Murray et al. 2009) and is usually considered to be exclusively marine, occurring in oceanic, neritic, and littoral environments (Hoppenrath \& Leander 2008). However, two species ( $P$. playfairi and $P$. foveolata) are described from Australian freshwaters and fresh coastal lagoons (Croome \& Tyler 1987).

Only a few epiphytic Prorocentrum species have been described. All these species are marine and mainly associated with the production of okadaic acid or its analogues. Moreover they often constitute a significant part of water toxin producers. These epiphytic Prorocentrum species are cosmopolitan and the majority has been described from tropical and subtropical waters of the Caribbean Sea, Pacific and Indian Oceans (Aligizaki et al. 2009).

However, a new epiphytic Prorocentrum taxon has been recorded in the Vienne and Aurence rivers in France in 2009. Thus the aim of this study is to describe the morphology and the phylogeny of this rare species which has particular distribution and ecological needs.

\section{Materials and methods}

\subsection{SEM preparation}

Macrophyte samples covered with epiphytic microalgae were collected in the Vienne river near the Fournet bridge ( $45^{\circ} 42^{\prime} 42^{\prime \prime} \mathrm{N} 1^{\circ} 52^{\prime} 17^{\prime \prime} \mathrm{E}$, Rempnat, Haute-Vienne, France) and in the Aurence river near the north industrial zone of Limoges $\left(45^{\circ} 52^{\prime} 86^{\prime \prime} \mathrm{N} 1^{\circ} 16^{\prime} 77^{\prime \prime} \mathrm{E}\right.$, Limoges, Haute-Vienne, France). The biological material was fixed overnight in a Sorensen's phosphate buffer $\left(75 \% \quad \mathrm{NaH}_{2} \mathrm{PO}_{4}(\mathrm{v} / \mathrm{v}), 25 \% \quad \mathrm{KH}_{2} \mathrm{PO}_{4}(\mathrm{v} / \mathrm{v}), \mathrm{pH} 7.2\right)$ containing $2.5 \%$ glutaraldehyde $(\mathrm{v} / \mathrm{v})$. Samples for scanning electron microscopy (SEM) were dehydrated in an ethanol graded series $\left(10^{\circ}\right.$ ethanol (1x), 30 ethanol (1x), 50 ethanol (1x), $70^{\circ}$ ethanol $(1 \mathrm{x}), 90^{\circ}$ ethanol (1x), absolute ethanol (4x)), sputter-coated with gold, and observed using a FEI Quanta 200 SEM.

\subsection{Choice of the phylogenetic method}

Despite of 99 investigations in nine Vienne and Aurence river stations on macrophytic and benthic substrates, and in the water column, only two populations were found. Only morphological characters could be observed on this new species because of their SEM preparation. Its place in the Prorocentrum genus phylogeny was done by applying the robust and widely used polyphasic method (Berrendero et al. 2008; Cameron \& Williams 2003; Varga et al. 2007; Yli-Mattila et al. 2002): some morphological characters from 25 Prorocentrum species and from the new species were used to establish cladisitic relationships between taxa and then materialized in a cladogram. Some gene sequences of the 25 species were also used to put evolution quantifications in the same phylogenetic analysis in order to transform the precedent cladogram into a phylogram. The efficiency of this phylogenetic methodology combining morphological and molecular data, particularly in the case when some important data such as the genetic sequence of the studied species is missing, has been proved especially in palaeobiological studies where molecular data lack (Giribet 2010; Springer et al. 2001). Indeed, the question of missing data has been evaluated in detail by many authors who agree in that missing data do not affect the phylogenetic 
analysis (Kearney 2002; Norell \& Wheeler 2003; Wenzel \& Siddall 1999; Wiens 1998, 2003, 2005, 2006).

\subsection{Morphological characters}

All morphological characters used in this study are listed in Tables 1 and 2. These characters were commonly used in the taxa discrimination of the Prorocentrum genus (CohenFernandez et al. 2006; Cortés-Altamirano \& Sierra-Beltrán 2003; Faust 2008; Grzebyk et al. 1998 ) because of their relevance in the species determination. Thus they were of important advised interest here. They were coded as discrete with the exception of two characters treated as continue and measured with the biometric software Visilog 6.404 Viewer (Noesis 2005).

\subsection{RNA sequences and alignment}

The LSU rRNA gene sequences from 25 Prorocentrum species (Tables 1 and 2) were aligned using the CLUSTAL $X$ algorithm (Thompson et al. 1997). The monophyly of the Prorocentrum genus has been proved several times (Hoppenrath \& Leander 2008; Saldarriaga et al. 2004) so no outgroup is necessary. The open and extended gap penalties were set to 10 and 5 , respectively.

\subsection{Phylogenetic analyses}

An unweighted maximum parsimony (MP) phylogenetic analysis of the aligned sequences was performed using the PHYLIP program (Felsenstein 1989). All parsimony analyses utilized branch and bound searches, unless otherwise indicated. MP tree was estimated for the combined nucleotide and morphological data sets. Gaps were coded as single characters, regardless of their length, and appended to the nucleotide data matrix. Bootstrap analyses implemented in PHYLIP (heuristic search, 500 replicates, branch swapping) were performed to provide measures of relative support for each node estimated in the maximum parsimony tree.

\section{Results}

3.1. Prorocentrum rivalis Delmail, Labrousse, Crassous, Hourdin, Guri et Botineau sp. nov. (Fig. 1 a-c).

Latin diagnosis. Cellula photosynthetica, ovata, 9.9-15.3 $\mu \mathrm{m}$ longa et 3.4-6.4 $\mu \mathrm{m}$ lata. Valvae convexae, poris numerosi. Area apical valvae dextra ovata. Porus flagellaris magnus et pori apicali parvuli et sine spina apicale. Balteus intercalaris horizontale striatus.

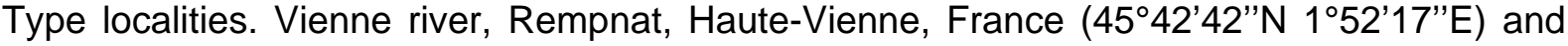

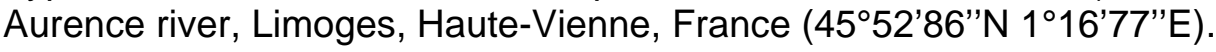


Holotype. Collected in nature in April 2009 and deposited at the LIMO Herbarium (Fig. 1 a-c).

Etymology. rivalis (Latin, "from river sites") referring to the freshwater distribution of this species.

General morphology. Ovate cell, 9.9-15.3 $\mu \mathrm{m}$ long, 3.4-6.4 $\mu \mathrm{m}$ wide. Overall shape biconvex. Valve surface smooth with marginal pores. Pores uniformly small with smooth margin ranging in diameter from 0.07 to $0.010 \mu \mathrm{m}$ (Fig. 1b). Periflagellar area like an ovoid depression in the anterior end of the right valve (Fig. 1C). Flagellar pore large and ovate. Auxiliary pores smaller, narrow and ovate. Periflagellar area without ornamentation such as an apical spine. Intercalary band horizontally striated.

Occurrence. This species was recorded in the Vienne and Aurence rivers in April 2009. The species does not co-occurred with other Prorocentrum species.

Habitat. The Vienne river is one of the most important rivers in south-western France, a significant left tributary of the lower Loire. The Aurence river is a 27-km tributary to the Vienne river which flows along the town of Limoges' northern and western boundaries. These two rivers have very close chemical properties listed in Table 3. $P$. rivalis lives in a river environment, epiphytic on the macrophyte Myriophyllum alterniflorum (Haloragaceae). Only a mucilage allows the adhesion of $P$. rivalis on the macrophyte leaves. Other macrophyte taxa co-occur in this environment (Callitriche hamulata (Plantaginaceae), Ranunculus peniciliatus (Ranunculaceae), Fontinalis squamosa (Fontinalaceae), Dermatocarpon weberi (Verrucariaceae)). The lighting is shade due to the presence of many caducifoliate trees, the water column is shallow and the water flow is heavy.

\subsection{Phylogenetic relationships}

Determining the ecological clades is the best way to process and understand the Prorocentrum phylograms (Hoppenrath \& Leander 2008; Murray et al. 2009). The Prorocentrum species could be separated in two different ecological clades (Fig.2). A high bootstrap support value is noted for the planktonic clade (83.4). The studied species, except those in the previous planktonic clade, form a paraphyletic benthic/epiphytic clade. However three planktonic species ( $P$. foveolata, $P$. playfairi and $P$. arabianum) are distributed in the paraphyletic clade. $P$. rivalis sp. nov. is epiphytic and is part of the paraphyletic clade. This new species has close relationships to $P$. playfairi, $P$. foveolata and $P$. borbonicum.

\section{Discussion}

$P$. rivalis sp. nov. is branched within paraphyletic clade with high statistical support (bootstrap of 100$)$. The most closely related species to $P$. rivalis sp. nov. are the planktonic freshwater species ( $P$. playfairi and $P$. foveolata) and the epiphytic marine $P$. borbonicum which form a distinct clade with high statistical support (bootstrap of 100). These three species are also the most similar to $P$. rivalis sp. nov. from a morphological perspective (Tables 1 and 2). All four species are small, have an ovate cell shape and an unornamented periflagellar area.

From an evolutionary point of view, the most parsimonious theory is to consider that the ancestor of the four-species clade was epiphytic and acquired freshwater ecophysiology. $P$. 
borbonicum ancestors undergo later an ecophysiological reversion to become marine and ancestors of the two Australian freshwater species developed later the planktonic way of life. Due to the phylogenetic proximity of the three freshwater species, these previous common morphological characteristics could be typical of a freshwater Prorocentrum ecophenotypy.

Our analysis confirmed earlier reports that Prorocentrum species form two distinct ecological clades (Grzebyk et al. 1998; Hoppenrath \& Leander 2008; Litaker et al. 1999; Murray et al. 2005; Saldarriaga et al. 2004): a benthic/epiphytic clade and a planktonic clade (Fig. 2).

Saldarriaga et al. (2004) have reported a weakly supported sister relationship between the two Prorocentrum ecological clades in phylogenetic analyses of LSU rDNA sequences which is highlighted in our study by the presence of three planktonic species ( $P$. foveolata, $P$. playfairi and $P$. arabianum) in the benthic/epiphytic clade. These three species could be considered as homoplasies due to convergent ecological evolution with the planktonic clade which is polyphyletic. In further studies it would be important to increase the number of sequenced species and individuals to enhance the phylogenetic resolution of this sister relationship and to confirm it.

However, the Prorocentrales form a robust monophyletic group with no ecological differentiation from a morphological and cladisitical perspective, but phylogenetic studies do not refute the monophyly of this order and provide significant insights into the evolutionary history (Hoppenrath \& Leander 2008; Saldarriaga et al. 2004). Indeed our polyphasic study suggests that planktonic Prorocentrum species are evolutionarily derived from epiphytic/benthic prorocentroid ancestors as the ecology of the less derived Prorocentrum species is epiphytic ( $P$. emarginatum) and benthic ( $P$. sculptile). However, the number of independent convergences/reversions from a benthic to a planktonic mode of life remains unknown and currently molecular phylogenetic data using ribosomal gene sequences cannot adequately address hypotheses of ecophysiological evolution within the Prorocentrum genus. Our knowledge of Prorocentrum diversity and the exploration of several different molecular phylogenetic markers, such as nucleus encoded protein genes must be improved (Hoppenrath \& Leander 2008).

Concerning the ecophysiology, $P$. rivalis $\mathrm{sp}$. nov. is found epiphytically in freshwater habitats. Studies on microorganisms attest that predominantly marine species could also occasionally survive in low-salt environments (Rengefors et al. 2008). However, the localities where this new species was found are not in the vicinity of any marine or brackish water inputs. Indeed these stations are located at $183 \mathrm{kms}$ for the Aurence locality and at $245 \mathrm{kms}$ for the Vienne locality from the nearest salt waters of the Atlantic Ocean. Thus $P$. rivalis $\mathrm{sp}$. nov. appears to be a truly freshwater species with no marine affinities.

As said previously, the genus Prorocentrum is predominantly present in marine waters and tolerate high intensities of photosynthetically active radiation (PAR) spanning most of the spectrum and so have pigment adaptations (Helbling et al. 2008). However, $P$. rivalis sp. nov. is present in shallow waters where PAR is restricted to the red end of the spectrum (Luria \& Kinney 1970). It would be useful to study the photosynthetic pigment characteristics of $P$. rivalis sp. nov. and to compare them with the two other freshwater Prorocentrum species. Moreover it will be interesting to see if biochemical pathways present in $P$. rivalis sp. nov. lead to the production of toxins like their epiphytic marine relatives.

Thus it would be essential to multiply ex situ investigations to find many $P$. rivalis sp. nov. specimens to develop their in vitro culture in order to sequence parts of its genome for phylogeny and to analyze its biochemical components like eventual toxins. It would be also important to make ecological studies about natural populations of $P$. rivalis sp. nov. (e.g. dynamics, reproduction) to evaluate the rarity degree of this species because it is only present in $2 \%$ of the 99 studied localities. 


\section{Acknowledgments}

This study was carried out within the Laboratory of Botany and Cryptogamy set at the Faculty of Pharmacy of Limoges (University of Limoges) and within the Laboratory of Deep Environments set at the IFREMER of Plouzané. This research was supported by the Conseil Régional du Limousin and the GRESE EA 4330 (University of Limoges). The authors thank Jean Jaouen (DDASS de la Haute-Vienne) for providing data about the water chemistry and Dr. Judit Padisák (University of Veszprém) for her editing of the English text.

\section{References}

Aligizaki K., Nikolaidis G., Katikou P., Baxevanis A.D. \& Abatzopoulos T.J. 2009. Potentially toxic ephytic Prorocentrum (Dinophyceae) species in Greek coastal waters. Harmful Algae 8: 299-311.

Berrendero E., Perona E. \& Mateo P. 2008. Genetic and morphological characterization of Rivularia and Calothrix (Nostocales, Cyanobacteria) from running water. Int. J. Syst. Evol. Microbiol. 58: 447-460.

Cameron S.A. \& Williams P.H. 2003. Phylogeny of bumble bees in the New World subgenus Fervidobombus (Hymenoptera: Apidae): congruence of molecular and morphological data. Mol. Phylogenet. Evol. 28: 552-563.

Cohen-Fernandez E.J., Meave Del Castillo E., Salgado Ugarte I.H. \& Pedroche F.F. 2006. Contribution of external morphology in solving a species complex: The case of Prorocentrum micans, Prorocentrum gracile and Prorocentrum sigmoides (Dinoflagellata) from the Mexican Pacific Coast. Phycological Res. 54: 330-340.

Cortés-Altamirano R. \& Sierra-Beltrán A.P. 2003. Morphology and taxonomy of Prorocentrum mexicanum and reinstatement of Prorocentrum rhathymum (Dinophyceae). J. Phycology 39: 221-225.

Croome R.L. \& Tyler P.A. 1987. Prorocentrum playfairi and Prorocentrum foveolata, two new Dinoflagellates from Australian freshwaters. Eur. J. Phycology 22: 67-75.

Faust M.A. 1990. Morphologic details of six benthic species of Prorocentrum (Pyrrophyta) from a mangrove island, twin cays, Belize, including two new species. J. Phycology 26: 548558.

Faust M.A. 1993. Prorocentrum belizeanum, Prorocentrum elegans and Prorocentrum caribbaeum, three new benthic species (Dinophyceae) from a mangrove island Twin Cays, Belize. J. Phycology 29: 100-107.

Faust M.A. 1994. Three new benthic species of Prorocentrum (Dinophyceae) from Carrie Bow Cay, Belize: $P$. sabulosum sp. nov., $P$. sculptile sp. nov., and $P$. arenarium sp. nov. J. Phycology 30: 755-763.

Faust M.A. 2008. Prorocentrum levis, a new benthic species (Dinophyceae) from a mangrove island, Twin Cays, Belize. J. Phycology 44: 232-240.

Felsenstein J. 1989. PHYLIP - Phylogeny Inference Package (Version 3.2). Cladistics 5: 164-166. 
Fukuyo Y. 2004. Biological Character of Red-Tide Organisms, pp. 61-178. In: Okaichi T. (ed), Red Tides, Terra Scientific Publishing Company, Tokyo.

Giribet G. 2010. A new dimension in combining data? The use of morphology and phylogenomic data in metazoan systematics. Acta Zool. 91: 11-19.

Grzebyk D., Sako Y. \& Berland B. 1998. Phylogenetic analysis of nine species of Prorocentrum (Dinophyceae) inferred from 18S ribosomal DNA sequences, morphological comparisons and description of Prorocentrum panamensis, sp. nov. J. Phycology 34: 10551068.

Helbling E.W., Buma A.G.J., van de Poll W., Fernández Zenoff M.V. \& Villafañe V.E. 2008. UVR-induced photosynthetic inhibition dominates over DNA damage in marine dinoflagellates exposed to fluctuating solar radiation regimes. J. Exp. Mar. Biol. Ecol. 365: 96-102.

Hernández-Becerril D.U., Cortés Altamirano R. \& Alonso R.R. 2000. The dinoflagellate genus Prorocentrum along the coasts of the Mexican Pacific. Hydrobiologia 418: 111-121.

Hoppenrath M. \& Leander B.S. 2008. Morphology and molecular phylogeny of a new-marine sand-dwelling Prorocentrum species, P. tsawwassenense (Dinophyceae, Prorocentrales), from British Columbia, Canada. J. Phycology 44: 451-466.

Kearney M. 2002. Fragmentary taxa, missing data, and ambiguity: Mistaken assumptions and conclusions. Systemat. Biol. 51: 369-381.

Krakhmalnyy A.F. 2005. Prorocentrum dentatum - New for the Black Sea species of Dinoflagellata. Vestnik Zoologii 39: 61-64.

Litaker R.W., Tester P.A., Colorni A., Levy M.G. \& Noga E.J. 1999. The phylogenetic relationship of Pfiesteria piscicida, Cryptoperidiniopsoid sp., Amyloodinium ocellatum and a Pfiesteria-like dinoflagellate to other dinoflagellates and apicomplexans. J. Phycology 35: 1379-1389.

Lu D. \& Goebel J. 2001. Five red tide species in genus Prorocentrum including the description of Prorocentrum donghaiense Lu sp. nov. from the East China Sea. Chin. J. Oceanol. Limnol. 19: 337-344.

Lu D., Goebel J., Qi Y., Zou J., Han X., Gao Y. \& Li Y. 2005. Morphological and genetic study of Prorocentrum donghaiense Lu from the East China Sea, and comparison with some related Prorocentrum species. Harmful Algae 4: 493-505.

Luria S.M. \& Kinney J.A. 1970. Underwater vision. Science 167: 1454-1461.

Morton S.L. 1998. Morphology and toxicology of Prorocentrum faustiae sp. nov., a toxic species of non-planktonic Dinoflagellate from Heron Island, Australia. Botanica Marina 41: 565-569.

Morton S.L., Faust M.A., Fairey E.A. \& Moeller P.D.R. 2002. Morphology and toxicology of Prorocentrum arabianum sp. nov., (Dinophyceae) a toxic planktonic dinoflagellate from the Gulf of Oman, Arabian Sea. Harmful Algae 1: 393-400.

Murray S., Flø Jørgensen M., Ho S.Y.W., Patterson D.J. \& Jermiin L.S. 2005. Improving the analysis of dinoflagellate phylogeny based on rDNA. Protist 156: 269-286. 
Murray S., Ip C.L.C, Moore R., Nagahama Y. \& Fukuyo Y. 2009. Are Prorocentroid Dinoflagellates monophyletic ? A study of 25 species based on nuclear and mitochondrial genes. Protist 160: 245-264.

Murray S., Nagahama Y. \& Fukuyo Y. 2007. Phylogenetic study of benthic, spine-bearing prorocentroids, including Prorocentrum fukuyoi sp. nov. Phycological Res. 55: 91-102.

Noesis. 2005. Visilog6-Viewer. Version 6.404. Noesis, Crolles.

Norell M.A. \& Wheeler W.C. 2003. Missing entry replacement data analysis: A replacement approach to dealing with missing data in paleontological and total evidence data sets. J. Vertebr. Pal. 23: 275-283.

Rengefors K., Laybourn-Parry J., Logares R., Marshall W.A. \& Hansen G. 2008. Marinederived dinoflagellates in Antarctic saline lakes: Community composition and annual dynamics. J. Phycology 44: 592-604.

Saldarriaga J.F., Taylor F.J.R., Cavalier-Smith T., Menden-Deuer S. \& Keeling P.J. 2004. Molecular data and the evolutionary history of dinoflagellates. Eur. J. Protist. 40: 85-111.

Springer M.S., Teeling E.C., Madsen O., Stanhope M.J. \& de Jong W.W. 2001. Integrated fossil and molecular data reconstruct bat echolocation. PNAS 98: 6241-6246.

Steidinger K.A. \& Tangen K. 1996. Dinoflagellates, pp. 387-598. In: Tomas C.R. (ed), Identifying Marine Diatoms and Dinoflagellates, Academic Press, New York.

Ten-Hage L., Turquet J., Quod J.P., Puiseux-Dao S. \& Couté A. 2000. Prorocentrum borbonicum sp. nov. (Dinophyceae), a new toxic benthic dinoflagellate from the southwestern Indian Ocean. Phycologia 39: 296-301.

Thompson J.D., Gibson T.J., Plewniak F., Jeanmougin F. \& Higgins D.G. 1997. The CLUSTAL $X$ windows interface: flexible strategies for multiple sequence alignment aided by quality analysis tools. Nucl. Acids Res. 24: 4876-4882.

Varga J., Frisvard J.C. \& Samson R.A. 2007. Polyphasic taxonomy of Aspergillus section Candidi based on molecular, morphological and physiological data. Stud. Mycol. 59: 75-88.

Wenzel J.W. \& Siddall M.E. 1999. Noise. Cladistics 15: 51-64.

Wiens J.J. 1998. Does adding characters with missing data increase or decrease phylogenetic accuracy? Systemat. Biol. 47: 625-640.

Wiens J.J. 2003. Missing data, incomplete taxa, and phylogenetic accuracy. Systemat. Biol. 52: 528-538.

Wiens J.J. 2005. Can incomplete taxa rescue phylogenetic analyses from long-branch attraction? Systemat. Biol. 54: 731-742.

Wiens J.J. 2006. Missing data and the design of phylogenetic analyses. J. Biomed. Inform. 39: $34-42$.

Yli-Mattila T., Paavanen-Huhtala S., Bulat S.A., Alekhina I.A. \& Nirenberg H.I. 2002. Molecular, morphological and phylogenetic analysis of the Fusarium avenaceum/F. arthrosporioides/F. tricinctum species complex - A polyphasic approach. Mycol. Res. 106: 655-669. 


\section{Tables}

Table 1. LSU rRNA GenBank accession numbers and morphological characters of the 13 planktonic Prorocentrum species used in the polyphasic phylogenetic analysis. The number in brackets below the discrete/continue value of the morphological character corresponds to the article which references the data: (1) Grezbyk and Sako, 1998; (2) Cortés-Altamirano and Sierra-Beltrán, 2003; (3) Hernández-Becerril et al. 2000; (4) Steidinger and Tangen, 1996; (5) Fukuyo, 2004; (6) Krakhmalnyy, 2005; (7) Lu and Goebel, 2001; (8) Lu et al. 2005; (9) Morton et al. 2002; (10) Croome and Tyler, 1987; (11) Cohen-Fernandez et al. 2006.

\begin{tabular}{|c|c|c|c|c|c|c|c|c|c|c|}
\hline & \multirow[b]{2}{*}{$\begin{array}{l}\text { LSU } \\
\text { rRNA }\end{array}$} & \multicolumn{3}{|c|}{ Cell morphology } & \multicolumn{4}{|c|}{ Valve surface } & \multicolumn{2}{|c|}{ Periflagellar area } \\
\hline & & $\begin{array}{l}\text { Length } \\
(\mu \mathrm{m})\end{array}$ & $\begin{array}{l}\text { Width } \\
(\mu \mathrm{m})\end{array}$ & Cell shape & $\begin{array}{l}\text { Concave vs. } \\
\text { convex }\end{array}$ & Intercalary band & Ornament & Pore pattern & $\begin{array}{c}\text { Shape in } \\
\text { apical view }\end{array}$ & Ornament \\
\hline P. arabianum Morton \& Faust & EF566752 & $45.0^{(9)}$ & $37.5^{(9)}$ & Ovate $^{(9)}$ & Concave $^{(9)}$ & $\begin{array}{l}\text { Horizontally } \\
\text { striated }^{(9)}\end{array}$ & Depressions ${ }^{(9)}$ & Scattered ${ }^{(9)}$ & V-shaped ${ }^{(9)}$ & None ${ }^{(9)}$ \\
\hline P. balticum (Lohmann) Loeblich III & AF042816 & $9.5^{(7)}$ & $13.5^{(7)}$ & Ovate $^{(4)}$ & Convex $^{(4)}$ & $\begin{array}{l}\text { Transversally } \\
\text { striated }^{(4)}\end{array}$ & Spines ${ }^{(4)}$ & Scattered ${ }^{(4)}$ & V-shaped ${ }^{(4)}$ & Spine $^{(4)}$ \\
\hline P. compressum (Bailey) Abé ex Dodge & EF517256 & $40.0^{(4)}$ & $27.5^{(4)}$ & Ovate $^{(4)}$ & Convex ${ }^{(4)}$ & Smooth ${ }^{(4)}$ & Depressions ${ }^{(4)}$ & Scattered ${ }^{(4)}$ & V-shaped ${ }^{(4)}$ & Spine $^{(4)}$ \\
\hline P. dentatum Stein & AY863006 & $18.5^{(3)}$ & $9.0^{(3)}$ & Pyriform $^{(3)}$ & Convex ${ }^{(3)}$ & Smooth ${ }^{(6)}$ & Spines ${ }^{(3)}$ & Marginal ${ }^{(3)}$ & Oblong ${ }^{(6)}$ & None ${ }^{(6)}$ \\
\hline P. donghaiense Lu & EU586259 & $19.0^{(7)}$ & $11.8^{(7)}$ & Pyriform ${ }^{(7)}$ & Convex $^{(7)}$ & $\begin{array}{l}\text { Horizontally } \\
\text { striated }^{(8)}\end{array}$ & Spines $^{(7)}$ & Scattered ${ }^{(7)}$ & V-shaped ${ }^{(7)}$ & None ${ }^{(8)}$ \\
\hline P. foveolata Croome \& Tyler & AY259173 & $27.5^{(10)}$ & $20.5^{(10)}$ & Ovate ${ }^{(10)}$ & Concave $^{(10)}$ & $\begin{array}{l}\text { Transversally } \\
\text { striated }^{(10)}\end{array}$ & Depressions ${ }^{(10)}$ & Scattered $^{(10)}$ & Ovoid $^{(10)}$ & None ${ }^{(10)}$ \\
\hline P. gracile Schütt & EF517251 & $50.0^{(11)}$ & $24.0^{(11)}$ & Pyriform ${ }^{(11)}$ & Convex ${ }^{(11)}$ & Smooth ${ }^{(11)}$ & Depressions $^{(11)}$ & Radial lines ${ }^{(11)}$ & Oblong $^{(11)}$ & Spine ${ }^{(11)}$ \\
\hline P. mexicanum Osorio Tafall & AF260378 & $35.0^{(1)}$ & $22.5^{(1)}$ & Ovate $^{(1)}$ & Convex $^{(2)}$ & Smooth $^{(2)}$ & Depressions ${ }^{(1)}$ & Radial lines $^{(1)}$ & Ovoid $^{(1)}$ & Spine $^{(1)}$ \\
\hline P. micans Ehrenberg & EF517257 & $52.5^{(1)}$ & $35.0^{(1)}$ & Pyriform ${ }^{(1)}$ & Convex $^{(4)}$ & Smooth $^{(4)}$ & Depressions ${ }^{(1)}$ & Radial lines $^{(1)}$ & Oblong $^{(1)}$ & Spine $^{(1)}$ \\
\hline P. minimum (Pavillard) Schiller & EF517247 & $16.5^{(1)}$ & $15.5^{(1)}$ & Ovate $^{(1)}$ & Convex $^{(5)}$ & Smooth $^{(5)}$ & Spines ${ }^{(1)}$ & Scattered ${ }^{(1)}$ & Ovoid $^{(1)}$ & Spine $^{(1)}$ \\
\hline P. playfairi Croome \& Tyler & AY259175 & $45.0^{(10)}$ & $33.5^{(10)}$ & Ovate $^{(10)}$ & $\begin{array}{l}\text { Concave and } \\
\text { convex }{ }^{(10)}\end{array}$ & Smooth $^{(10)}$ & Depressions $^{(10)}$ & Scattered $^{(10)}$ & Ovoid $^{(10)}$ & None ${ }^{(10)}$ \\
\hline P. sigmoides Bohm & EF566746 & $72.0^{(11)}$ & $21.5^{(11)}$ & Pyriform ${ }^{(11)}$ & Convex ${ }^{(11)}$ & Smooth ${ }^{(11)}$ & Spines ${ }^{(11)}$ & Radial lines ${ }^{(11)}$ & Oblong ${ }^{(11)}$ & Spine ${ }^{(11)}$ \\
\hline P. triestinum Schiller & AY863010 & $21.5^{(3)}$ & $11.5^{(3)}$ & Pyriform ${ }^{(3)}$ & Convex $^{(3)}$ & Smooth $^{(3)}$ & Depressions ${ }^{(3)}$ & Scattered ${ }^{(3)}$ & V-shaped ${ }^{(3)}$ & None ${ }^{(3)}$ \\
\hline
\end{tabular}


Table 2. . LSU rRNA GenBank accession numbers and morphological characters of the 13 benthic/epiphytic Prorocentrum species used in the polyphasic phylogenetic analysis. The number in brackets below the discrete/continue value of the morphological character corresponds to the article which references the data: (1) Cortés-Altamirano and Sierra-Beltrán, 2003; (2) Hoppenrath and Leander, 2008; (3) Murray et al. 2007; (4) Grezbyk and Sako, 1998; (5) Faust, 2008; (6) Faust, 1993; (7) Morton et al. 2002; (8) Faust, 1990; (9) Ten-Hage et al. 2000; (10) Aligizakia et al. 2009; (11) Faust, 1994; (12) Morton, 1998.

\begin{tabular}{|c|c|c|c|c|c|c|c|c|c|c|}
\hline & \multirow[b]{2}{*}{$\begin{array}{l}\text { LSU } \\
\text { rRNA }\end{array}$} & \multicolumn{3}{|c|}{ Cell morphology } & \multicolumn{4}{|c|}{ Valve surface } & \multicolumn{2}{|c|}{ Periflagellar area } \\
\hline & & $\begin{array}{c}\text { Length } \\
(\mu \mathrm{m})\end{array}$ & $\begin{array}{l}\text { Width } \\
(\mu \mathrm{m})\end{array}$ & Cell shape & $\begin{array}{l}\text { Concave } \\
\text { vs. convex }\end{array}$ & $\begin{array}{l}\text { Intercalary } \\
\text { band }\end{array}$ & Ornament & Pore pattern & $\begin{array}{l}\text { Shape in } \\
\text { apical view }\end{array}$ & Ornament \\
\hline P. arenarium Faust & EF566747 & $31.0^{(5)}$ & $39.0^{(5)}$ & Ellipsoid $^{(5)}$ & Convex $^{(5)}$ & Smooth $^{(5)}$ & Smooth $^{(4)}$ & Marginal $^{(4)}$ & V-shaped ${ }^{(4)}$ & None ${ }^{(5)}$ \\
\hline P. belizeanum Faust & DQ238042 & $57.5^{(6)}$ & $52.5^{(6)}$ & Ovate $^{(6)}$ & Concave $^{(6)}$ & $\begin{array}{l}\text { Horizontally } \\
\text { striated }\end{array}$ & Areolae ${ }^{(6)}$ & Scattered ${ }^{(6)}$ & V-shaped ${ }^{(6)}$ & None ${ }^{(6)}$ \\
\hline $\begin{array}{l}\text { P. borbonicum Ten-Hage, Turquet, Quod, } \\
\text { Puiseux-Dao \& Couté }\end{array}$ & AJ567466 & $21.0^{(9)}$ & $18.0^{(9)}$ & Ovate $^{(9)}$ & Convex ${ }^{(10)}$ & $\begin{array}{l}\text { Horizontally } \\
\text { striated }^{(10)}\end{array}$ & Depressions ${ }^{(9)}$ & Scattered ${ }^{(9)}$ & V-shaped ${ }^{(9)}$ & None ${ }^{(9)}$ \\
\hline P. concavum Fukuyo & EF566751 & $52.5^{(4)}$ & $41.5^{(4)}$ & Ovate $^{(4)}$ & Concave $^{(8)}$ & $\begin{array}{l}\text { Horizontally } \\
\text { striated }^{(7)}\end{array}$ & Areolae $^{(4)}$ & Scattered ${ }^{(4)}$ & V-shaped ${ }^{(4)}$ & None ${ }^{(4)}$ \\
\hline P. emarginatum Fukuyo & EF566750 & $35.0^{(4)}$ & $29.5^{(4)}$ & Ovate $^{(4)}$ & Concave $^{(5)}$ & $\begin{array}{l}\text { Transversally } \\
\text { striated }^{(5)}\end{array}$ & Smooth ${ }^{(4)}$ & Radial lines ${ }^{(4)}$ & V-shaped ${ }^{(4)}$ & None ${ }^{(4)}$ \\
\hline P. faustiae Morton & EF566744 & $46.0^{(12)}$ & $40.0^{(12)}$ & Ovate ${ }^{(12)}$ & Concave $^{(12)}$ & $\begin{array}{l}\text { Horizontally } \\
\text { striated }{ }^{(7)}\end{array}$ & Depressions ${ }^{(12)}$ & Scattered ${ }^{(12)}$ & V-shaped ${ }^{(12)}$ & None ${ }^{(12)}$ \\
\hline P. fukuyoi Murray \& Nagahama & EU196416 & $35.0^{(3)}$ & $24.0^{(3)}$ & Oblong $^{(3)}$ & Convex $^{(3)}$ & $\begin{array}{l}\text { Horizontally } \\
\text { striated }^{(3)}\end{array}$ & Smooth ${ }^{(3)}$ & Radial lines ${ }^{(3)}$ & V-shaped ${ }^{(3)}$ & Spine ${ }^{(3)}$ \\
\hline P. hoffmannianum Faust & EU196415 & $50.0^{(8)}$ & $42.5^{(8)}$ & Ovate $^{(8)}$ & Concave $^{(8)}$ & Smooth ${ }^{(8)}$ & Areolae ${ }^{(8)}$ & Scattered ${ }^{(8)}$ & V-shaped ${ }^{(8)}$ & None ${ }^{(8)}$ \\
\hline $\begin{array}{l}\text { P. levis Faust, Kibler, Vandersea, Tester } \\
\& \text { Litaker }\end{array}$ & DQ238043 & $42.0^{(5)}$ & $38.5^{(5)}$ & Ellipsoid $^{(5)}$ & Concave $^{(5)}$ & Smooth ${ }^{(5)}$ & Smooth ${ }^{(5)}$ & Scattered $^{(5)}$ & V-shaped ${ }^{(5)}$ & None ${ }^{(5)}$ \\
\hline P. lima (Ehrenberg) Dodge & EF566748 & $39.0^{(4)}$ & $31.0^{(4)}$ & Ellipsoid $^{(5)}$ & Concave $^{(5)}$ & Smooth ${ }^{(5)}$ & Smooth ${ }^{(4)}$ & Marginal $^{(4)}$ & V-shaped ${ }^{(4)}$ & None ${ }^{(5)}$ \\
\hline $\begin{array}{l}\text { P. rhathymum Loeblich III, Sherley \& } \\
\text { Schmidt }\end{array}$ & EF566745 & $40.8^{(1)}$ & $25.5^{(1)}$ & Ovate $^{(1)}$ & Convex $^{(1)}$ & Smooth $^{(1)}$ & Depressions $^{(1)}$ & Radial lines ${ }^{(1)}$ & V-shaped ${ }^{(2)}$ & None $^{(1)}$ \\
\hline $\begin{array}{l}\text { P. rivalis sp. nov. Delmail, Labrousse, } \\
\text { Crassous, Hourdin, Guri \& Botineau }\end{array}$ & - & 12.6 & 4.9 & Ovate & Convex & $\begin{array}{l}\text { Horizontally } \\
\text { striated }\end{array}$ & Smooth & Marginal & Ovoid & None \\
\hline P. sculptile Faust & EF566749 & $34.5^{(11)}$ & $31.0^{(11)}$ & Ovate ${ }^{(11)}$ & Concave $^{(11)}$ & Smooth ${ }^{(11)}$ & Depressions ${ }^{(11)}$ & Scattered ${ }^{(11)}$ & V-shaped ${ }^{(11)}$ & None ${ }^{(11)}$ \\
\hline
\end{tabular}


Table 3. Water-column characteristics of the oligotrophic localities where Prorocentrum rivalis was observed (J. Jaouen, com. pers. 2009). Values are given with mean \pm standard deviations calculated from 3 monitoring measurements.

\begin{tabular}{llr}
\hline Property & Units & \\
\hline Conductivity & $\left(\mu \mathrm{S} . \mathrm{cm}^{-1}\right)$ & $49,0 \pm 3,0$ \\
$\mathrm{pH}$ & & $6,8 \pm 0,2$ \\
Total chlorides & $\left(\mathrm{mg} . \mathrm{l}^{-1}\right)$ & $5,0 \pm 0,9$ \\
Total sulfates & $\left(\mathrm{mg} . \mathrm{l}^{-1}\right)$ & $2,0 \pm 0,0$ \\
Nitrates & $\left(\mathrm{mg} . \mathrm{l}^{-1}\right)$ & $4,2 \pm 0,6$ \\
Nitrites & $\left(\mathrm{mg} . \mathrm{l}^{-1}\right)$ & $0,0 \pm 0,0$ \\
Total fluorides & $\left(\mathrm{mg} . \mathrm{l}^{-1}\right)$ & $0,1 \pm 0,0$ \\
Total phosphorus & $\left(\mathrm{mg} . \mathrm{l}^{-1}\right)$ & $0,1 \pm 0,0$ \\
Total organic carbon & $\left(\mathrm{mg} . \mathrm{l}^{-1} \mathrm{C}\right)$ & $3,8 \pm 0,6$ \\
Chemical oxygen demand & $\left(\mathrm{mg} . \mathrm{l}^{-1} \mathrm{O}_{2}\right)$ & $0,0 \pm 0,0$ \\
Turbidity & $(\mathrm{FNU})$ & $3,9 \pm 1,6$ \\
Suspended matter & $\left(\mathrm{mg} . \mathrm{l}^{-1}\right)$ & $8,0 \pm 4,4$ \\
\hline
\end{tabular}




\section{Figures}

Figure 1. Prorocentrum rivalis sp. nov. (a) Cell in right valve view is ovate and presents many marginal pores (scale bar $=5 \mu \mathrm{m}$ ). (b) Valve pores are uniformly small and round with a smooth margin (scale bar $=500 \mathrm{~nm}$ ). (c) Unornamented periflagellar area sets in an ovoid depression (scale bar $=5 \mu \mathrm{m}$ ).
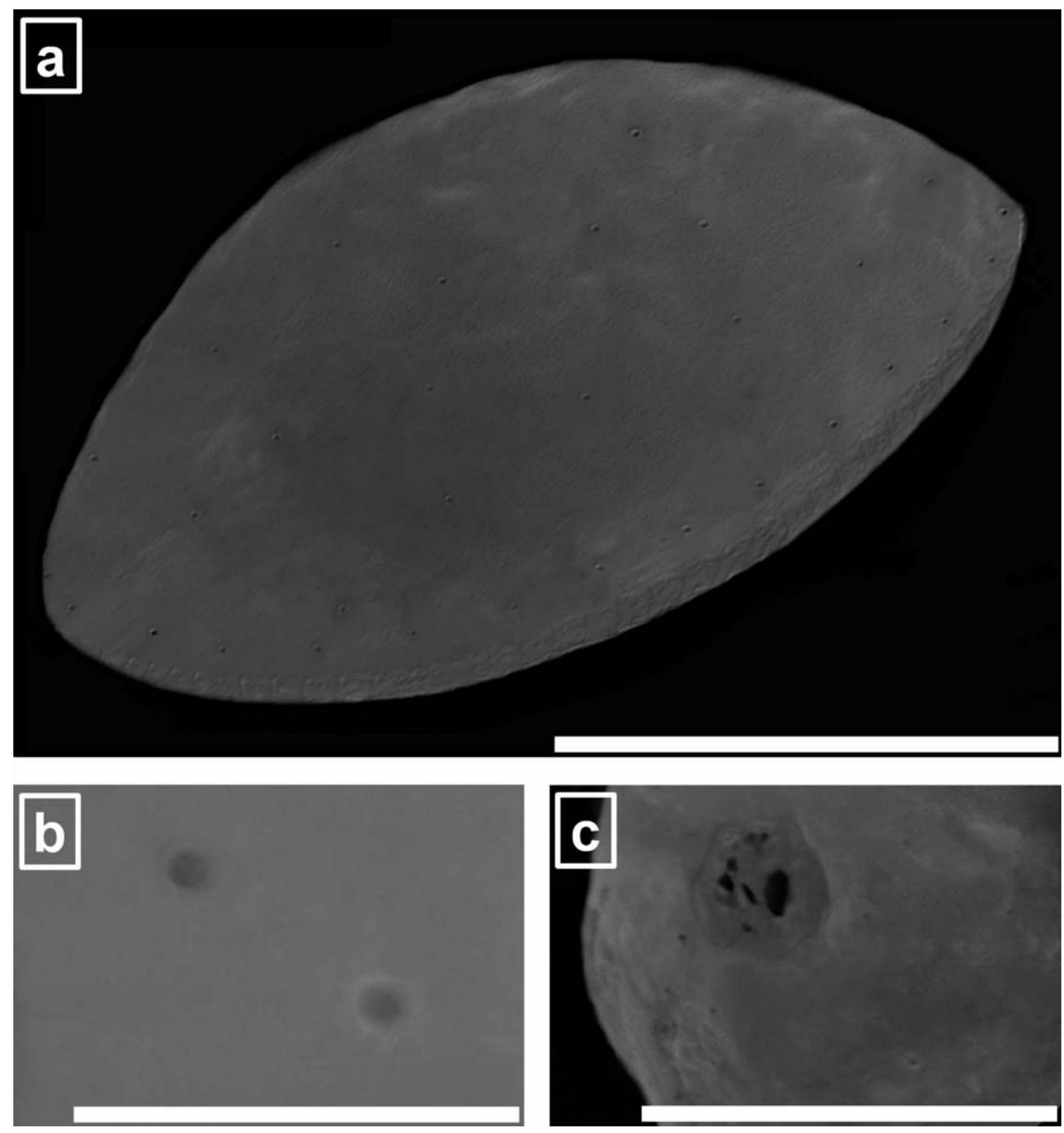
Figure 2. Maximum parsimony (MP) polyphasic phylogram based on the phenotypic and genetic relationships (9 morphological endpoints and LSU rRNA gene sequences) between 26 Prorocentrum species. An asterisk following the species name which belong to the polyphyletic planktonic clade. Other species belong to the paraphyletic epiphytic/benthic clade. A cross following the freshwater-species name while other species are marine. Bootstrap analyses (heuristic search, 500 replicates, branch swapping) are performed to provide measures of relative support for each node estimated in the maximum parsimony tree. GenBank accession numbers and morphological characters values of the species used for this analysis are listed in tables 1 and 2. 


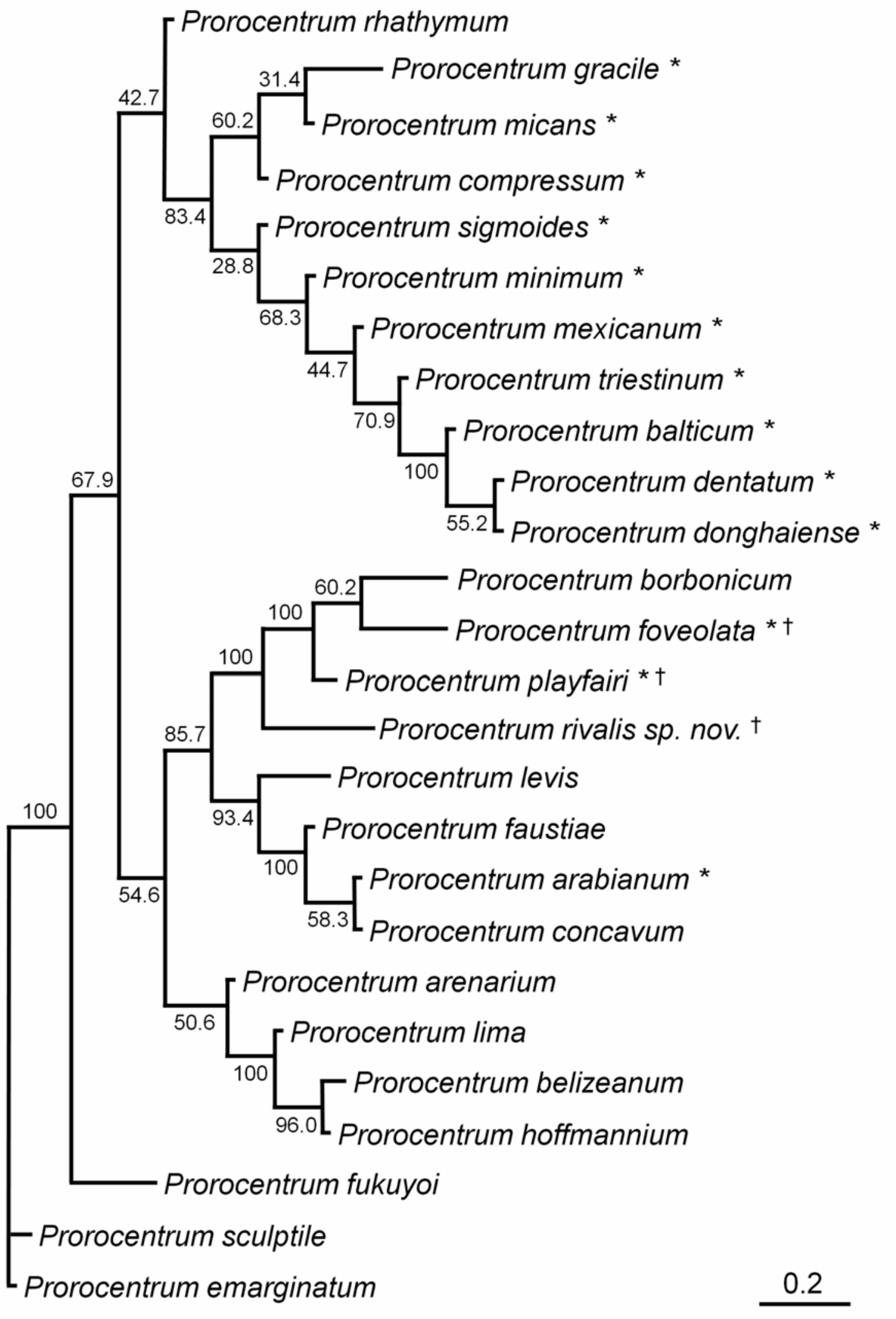

